\title{
ЛОНГРІД ЯК ФОРМА СУЧАСНОЇ МУЛЬТИМЕДІЙНОЇ ЖУРНАЛІСТИКИ
}

\author{
Уляна Лешко \\ Вінницький державний педагогічний університет імені Михайла Коиююинського, \\ вул. Острозького, 32, 21100, Вінниия, Украӥна \\ e-mail:leshko1@ukr.net \\ https://orcid.org/0000-0003-1260-3354
}

У статті здійснено теоретичний аналіз особливостей лонгріду та його функціонування як сучасної форми інтернет-медіа. Проаналізовано структурні елементи лонгріда, визначено основні типи, простежено специфіку використання мультимедійних історій у сучасних онлайн-медіа. 3'ясовано, що українська мережева жанрологія потребує єдиної концепції щодо визначення поняття «лонгрід». Запропоновано вважати лонгрід сучасною формою новітніх медіа та виділено такі типи: лонгрід-портрет, лонгрід-інтерв’ю, лонгрід-аналітична стаття, лонгрід-реконструктор, лонгрід-репортаж, логрід-фіче, лонгрід ньюс-фіче.

Ключові слова: лонгрід; мультимедійна історія; інтернет-журналістика; мультимедійна журналістика; нові медіа.

\section{1. Постановка проблеми.}

Унікальним середовищем та одночасно універсальною платформою подачі різноманітної інформації (текстової, аудіальної, візуальної) є сьогодні інтернет. Сучасний користувач має змогу бути активним учасником нового інфокомунікаційного процесу. Але цей процес передбачає використання специфічних форм і методів подачі повідомлень та активне залучення аудиторії до онлайн-комунікації. Інтернет-комунікація - це поліфункціональне спілкування в мережі, якому притаманні дистанційність, опосередкованість, мультимедійність, гіпертекстуальність, різноманітність жанрових форм, а також можливість широкої варіативності щодо параметрів персональність/ інституціональність ${ }^{1}$.

Інтернет сьогодні - це трансформована форма комунікаційної реальності, яка активно змінюється та удосконалюється. Ці зміни провокують виникнення нових явищ та жанрів. Популярними стають терміни «сторітелінг», «сноуфол», «лонгрід». Серед наукових доробків українських дослідників дедалі частіше трапляються дослідження, що стосуються цих нових форм та методів подачі інформації в мережі. Саме поняття «лонгрід» вимагає більш конкретного розгляду.

1 Колокольцева, Т. (2016), «Диалогичность в жанрах интернет-коммуникации (чат, форум, блог)», Жанры речи, № 2, с. 96-104.

(C) Лешко У., 2020 
Лешко У.

\section{2. Теоретичне підгрунтя.}

Серед українських та зарубіжних досліджень, що стосуються жанрових форм інтернет-журналістики, варто виділити праці науковців: О. Горошко, О. Градюшко, А. Захарченко, С. Землякової, О. Колесніченко, С. Коханов, І. Мацишиної, К. Пак, I. Тонкіх, М. Чабаненко, В. Шевченко, Л. Щипіциної.

\section{3. Методологічна основа дослідження.}

У роботі використано класичні методи дослідження змісту повідомлення. Завдяки порівняльному методу вдалось здійснити характеристику лонгріду в межах різних мережевих медіа, з’ясувати спільне та відмінне. Для аналізу досліджуваних матеріалів застосовано описовий метод. Журналістський аналіз тексту використовувався задля виявлення основних характеристик тексту, жанрової форми. Метод синтезу дав змогу поєднати усі елементи, виявлені в процесі дослідження, в єдину систему.

\section{4. Виклад основного матеріалу дослідження.}

Жанрові форми інтернет-медіа мають досить рухомі та розмиті межі, тому часто спостерігається поява гібридних жанрів, які не мають відповідників у паперових ЗМI, оскільки є продуктом інтернет-технологій. Якщо звернути увагу на особливості класифікації інтернет-жанрів, то можна окремо виділяти технологічну складову, яка безпосередньо впливає на структурування тексту в певній жанровій формі, його особливості функціонування в мережі. Використання інтернет-технологій дає змогу застосовувати в тексті фото, відео-, аудіозаписи, анімацію, інфографіку. А це впливає на зовнішній вигляд текстів, їхню структуру, зміст. Відповідно до цього дослідники пропонують нову класифікацію інтернет-жанрів, які грунтуються на трьох складових: технічному факторі (веб 1.0 - веб 2.0 - веб 3.0), ієрархічному (гіпержанр жанр - субжанр) та комунікативно-динамічному (традиційні комунікації, конвергенція, гібридизація, мутація) $)^{2}$.

I. Тонкіх зауважує, що мультимедійність стає головним фактором жанрових трансформацій і що замість поняття «мультимедійна стаття» можна вживати терміни «мультимедійна історія» або «лонгрід», але стверджує, що це швидше не жанр, а формат, у якому можуть синтезуватися різні журналістські жанри і поєднуватися вербальний і візуальний контент, а також елементи дизайну․․ Учені М. Булаєва, А. Галустян, Д. Кульчицька також вважають лонгрід форматом, оскільки в ньому можуть знайти відображення різні жанри (репортаж, нарис, розслідування). І. Мацишина лонгрід називає самостійною формою мультимедійної журналістики ${ }^{4}$.

Процес становлення поняття «лонгрід» (з анг. longread - довге читання) в онлайн-журналістиці активно триває, тому досить складно йому дати конкретну дефініцію. Усі визначення, які існують, тлумачать цей термін як велику мультимедійну історію з великими виразними ілюстраціями, відео, аудіо та інтерактивними картами. Л. Василик стверджує, що це «новий формат подачі текстової інформації

\footnotetext{
2 Горошко, Е., Полякова, Т. (2015), «К построению типологии жанров социальных медиа», Жанры речи, №2(12), с. 119-127.

3 Тонкіх, I. (2017), Інтернет-журналістика. Жанри в інтернеті: Навчальний посібник, ЗНТУ, Запоріжжя, с. 99-101.

4 Мацишина, I. (2017), «Структура мультимедійного сторітелінгу (на прикладі лонгріду)», Шевченко, В. (Ред.), Кросмедіа: контент, технології, перспективи (колективна монографія), Інститут журналістики Київського національного університету імені Тараса Шевченка, Київ, с. 149.
} 
в інтернеті. Коли віртуального тексту багато, його розбивають різними вставками: роликами, презентаціями, інтерактивними картинами, цитатами, виносками» 5 .

Натомість М. Чабаненко визначає лонгрід як «багатоформатний жанр інтернет-журналістики, розрахований на перегляд, передовсім, 3 гаджетів із сенсорними дисплеями»; «різновид інтернет-публікацій, цікава мультимедійна розповідь великого розміру» ${ }^{6}$. Також виділяє таймлайни - «хронологію розвитку якихось подій у форматі звичайного тексту» (можуть бути виконані як малюнок-схема у графічному редакторі та становити інфографіку); сторітелінг - «новий і одночасно старовинний спосіб донесення інформації... посідає одне з найпомітніших місць, виливаючись у великі мультимедійні матеріали, зокрема лонгріди» ${ }^{\text {. }}$

О. Градюшко, О. Колесніченко, М. Менчер зараховують лонгрід до аналітичних жанрів та порівнюють зі статтею, але акцентують на його більшій наочності подачі матеріалу за рахунок використання прикладів і репортажних вставок, які збагачують та полегшують сприйняття об'ємної інформації

Нові медіа дають можливість використовувати велику кількість інструментів, для створення мультимедійного контенту, тому популярності набуває сторітелінг. Важливою стає не просто подача журналістського тексту, а його презентація, доповнення ілюстративним наповненням, мультимедійним змістом. Але це мають бути не просто додаткові елементи, що привернуть увагу реципієнта, а інформативні елементи, що розповідатимуть історію.

Р. Вербовий вважає, що основною формою вияву сторітелінгу в нових медіа $є$ лонгрід. Але зауважує, що не варто ототожнювати ці поняття, бо якісний сторітелінг зараз часто використовується у пресі. «Сторітелінг - це радше метод, підхід до структурування та подачі журналістського матеріалу, натомість лонгрід - передусім формат медіа, готовий інформаційний продукт»?.

Лонгрід почали активно використовувати американські медіа. Це були великі текстові матеріали на сайтах, для прочитання яких потрібно було більше часу, ніж для традиційних журналістських матеріалів. Пізніше лонгрідом вважали великі тексти з вкрапленням відеосюжетів, фоторепортажу та інфографіки. Першим у світі лонгрідом вважається «Snowfall», який з'явився у 2012 році в «The New York Times». Цей текст став популярним не тому, що містив велику кількість мультимедійного матеріалу, а тому, що розповідав захопливу історію про лижників, які потрапили у

5 Крецу, І., Гузун, М. та Василик, Л. (2015), Підручник з крос-медіa, Bonn / Germany - Sibiu/ Romania, Schiller Publishing Youse, $140 \mathrm{c}$.

6 Чабаненко, М. (2018), Мультимедійність в інтернет-журналістиці: Навчально-методичний посібник для здобувачів ступеня вищої освіти бакалавра спеціальності «Журналістика», Просвіта, Запоріжжя, 80 с.

7 Там само.

8 Градюшко, А. (2016), «Современные мультимеийные форматы аналитических жанров журналистики», Вараб'ёв, В. (Ред.), Журналістыка у суладдз з жыциём: зб. навук. праи, БДУ, Мінск, c. 192-197; Колесниченко, А. (2015), «Длинные тексты (лонгриы) в современной российской прессе», Медиаско: электрон. журн. Факультета журналистики МГУ им. М. В. Ломоносова, Вып. 1. URL: http://www.mediascope.ru/node/1691

9 Вербовий, Р. (2017), «Інструментарій створення мультимедійного контенту», Шевченко, В. (Ред.), Кросмедіа: контент, технології, перспективи (колективна монографія), Ін-т журналістики Київського нац. ун-ту імені Тараса Шевченка, Київ, с. 83-90, 
пастку через лавину в горах у Вашингтоні. Якісний сюжет доповнюють мультимедійні засоби, що дозволяють стати співучасником події.

Дедалі більшої популярності набуває цей формат і в українських ЗМІ. Першими вітчизняними лонгрідами можна вважати: «Небесна сотня» («Українська правда», 2014), «Топ-20 музыкантов Украины» («Новое время», 2014), «Brexit. Уйти не прощаясь» («Дзеркало тижня»), «2014 рік. Революція гідності. Кульмінація», «Антиафіша: що робити на вихідних, якщо не хочеться виходити з дому» (медіаплатформа «Укрінформ»). Доволі популярним $є$ проект «The Ukrainians», який повністю побудований на лонгрідах-інтерв’ю. Часто лонгріди використовує і сайт ТСН телеканалу «1+1». Варто зазначити, що українським лонгрідам притаманна видовищність i змісту матеріалу, i його технічних особливостей. Зазвичай журналісти звертаються до специфічних тем (стихійні лиха, революції, катастрофи). Також спостерігається однотипність - використовують текст, фото, рідше відео та інфографіку.

До особливостей лонгріду можна віднести такі ознаки: драматична структура тексту з чітко окресленою сюжетною лінією, суб’єктивний характер викладу інформації, не проста констатація фактів, а розкриття драматичних елементів суспільно важливої події.

Для створення якісного лонгріду важливо спершу визначити цільову аудиторію, обрати цікаву й корисну тему та скласти план, лише тоді приступати до збору інформації, підготовки матеріалу (написання тексту, зйомка фото, відео, створення інфографіки) та оформлення. Текст має бути не тільки цікавим, зрозумілим для читача, а й створювати атмосферу занурення за допомогою мультимедійних засобів. Також корисним буде використання посилань на першоджерела, цитат, прикладів, модулів із закликом вподобати чи зробити репост.

Дослідники виділяють первинні структурні елементи лонгріду - текст 3 гіперпосиланнями, фото, відео або аудіо. Це обов'язкові компоненти, без яких не обходиться жодна мультимедійна історія. До другорядних елементів можна віднести слайд-шоу, інфографіку, карикатуру, інтерактивні форми (голосування, коментарі, рейтинги $)^{10}$.

Київський дослідник радить структурувати лонгріди за тематикою: різноманітні топи та дайджести, аналітичні підсумки у сфері політики, економіки, культури ${ }^{11}$.

Представники IT бізнесу в інтернеті пропонують доволі слушну типологію лонгріду: портрет людини (people story) - використовують фото, цитати друзів, родичів, унікальні життєві факти; репортаж - в основі може бути фото з анімацією, інтерв'ю, відео з події, аудіозаписи; аналітичний текст (реконструктор) - цитати фахівців, посилання на дослідження, фонову музику, відео ${ }^{12}$.

Якщо говорити про інтернет-медіа всеукраїнського масштабу, то можна стверджувати, що лонгріди тут містять різні структурні елементи, що забезпечує занурення читача в тему. Своєрідними лідерами щодо подачі інформації у такому форматі можна вважати інтернет-видання «Українська правда», «The Ukrainians», «Focus.ua».

\footnotetext{
${ }^{10}$ Крецу, І., Гузун, М. та Василик, Л. (2015), Підручник з крос-медіа, Bonn / Germany - Sibiu/ Romania, Schiller Publishing Youse, 140 c.

${ }^{11}$ Вербовий, Р. (2017), «Інструментарій створення мультимедійного контенту»...

12 WebMaestro, (2018), «Як зробити лонгрід, який дочитають до кінця?», доступно за адресою: https://webmaestro.com.ua/ua/blog/long-read/ (дата перегляду 20 листопада 2019).
} 
Своєрідною дифузією різних видів лонгрідів можна назвати публікацію «Святослав Вакарчук: «Я ніколи не заявляв, що збирався йти в президенти. Я нікому нічого не обіцяв» (Режим доступу. - https://www.pravda.com.ua). В основі яскраво простежуються репортажні елементи. Для читача відтворюються усі деталі спілкування з музикантом не лише за допомогою тексту, але й завдяки фото та відео: «...У невеликій кімнаті офісу його благодійного фонду «Люди майбутнього» в центрі Києва доволі тісно. I не в останню чергу через біле піаніно в кутку. Музикант, який до недавнього часу був одним із потенційних кандидатів у президенти, дивиться на склянку на фортепіано, посміхається, але відповідає цілком серйозно...»

Доволі розлоге інтерв’ю містить також елементи портрету, адже Святослав Вакарчук розповідає про свої перші кроки музиканта, науковця (захист дисертації), ділиться особистими переживаннями, принципами щодо виконання пісень наживо та участі у концертах, діяльності у політичній сфері. Велика кількість різнопланових запитань, яскравих фото та відео розмови дає можливість читачеві зануритись у тему бесіди, за допомогою запитань-пасток, провокативних запитань побачити справжні емоції респондента (саме світлини доповнюють цю картину). Це дійсно не просто журналістський текст, а об'ємна мультимедійна історія на важливу й актуальну тему з яскравими елементами напруження та динамізму.

Варто зазначити, що більшість інтерв’ю «Української правди» побудовані саме за таким принципом: велика кількість запитань та розлогі відповіді, різноформатні фото і респондента, i журналіста, які дають змогу побачити реальні емоції співрозмовника. До прикладу, в лонгріді «Сергій Рахманін: «Зеленський сприймає Верховну Раду як якийсь додаток до Офіса президента» (Режим доступу. - https://www. pravda.com.ua) подано світлини респондента у різні моменти розмови, його емоційні «малюнки» в робочому блокноті, зроблені під час спілкування. Тобто читач має змогу не тільки прочитати важливу інформацію, але й відчути себе співрозмовником, побачити справжні емоції Сергія Рахманіна.

«Тайны мормонов. Что происходит в одном из самых закрытых храмов Украины» - оригінальний приклад лонгріду-репортажу з елементами реконструктора (аналітичного тесту) з храму мормонів. Читач бачить храм зсередини, спілкується 3 представниками релігійної організації та має змогу зробити власні висновки (Режим доступу. - https://www.pravda.com.ua).

Онлайн-журнал про українців, ініціативу та відповідальність «The Ukrainians» також часто використовує таку мультимедійну форму подання матеріалу, як лонгрід. У межах рубрики «Репортажі» вміщують унікальні розповіді на різні теми. Усі тексти $є$ справжніми історіями з глибоким змістом, які доповнені змістовними, виразними та насиченими фото. Багатозначними та оригінальними є не лише заголовки таких публікацій, але й внутрішні підзаголовки, які використовуються у всіх матеріалах. Лонгріди «The Ukrainians» не містять відео, але дають змогу максимально зануритися в тему розповіді, побачити всі елементи та дрібниці, поєднують різні жанри (інтерв’ю, репортаж, коментар, стаття, журналістське розслідування). Наприклад, лонгрід-репортаж «Охоронці гірської погоди» дає змогу простежити особливості роботи метеорологів, провести день на засніженій метеостанції (Режим доступу. - https://theukrainians.org). 
Лешко У.

«Трава, що лікує» (Режим доступу. - https://theukrainians.org) - аналітичний текст з використанням рухомої анімації, в основі якого є фіче та оригінальна структура тексту з гіперпокликаннями (бекграундом до основної інформації).

Не менш оригінальними є лонгріди на інші теми: «Мед з історією», «На голці», «Жити, щоб шити». В окрему групу зібрано такий тип лонгріду, як peope story розповіді про жінок, які служать в ЗСУ «4.5.0 Захисниці». Мережеве видання «Тһе Ukrainians» вміло доповнює об'ємні тексти ілюстративним матеріалом, смислові акценти, які забезпечують часто внутрішні підзаголовки, роблять саме якісні та неординарні світлини.

«Focus.ua» - один з небагатьох ресурсів, який створює якісні лонгріди високого професійного рівня і щодо технічного виконання, і щодо структурування тексту та змістового наповнення. Рубрика «Длинный фокус» присвячена саме цій формі викладу цікавих та важливих тем. Більшість текстів тут, які викладені у формі лонгріду, є ньюс-фіче - жанр, який створений не для опису окремих подій, а тенденцій, які помітив журналіст за цими подіями ${ }^{13}$. Використовуючи певні події як приклади, журналіст показує тренд, якого до нього ніхто не помічав, і робить висновки, які до нього ніхто не робив. До прикладу, «Бросить школу» - публікація про тренд, який помітив автор (батьки забирають дітей зі школи з різних причин і навчають їх вдома), містить кілька історій, відбувається зміна крупних і загальних планів подання інформації, є бекграунди і кікер - неочікуваний поворот теми наприкінці тексту (Режим доступу. - https://focus.ua/long, 4.11.2019). До цієї групи також можна зарахувати: «Війна тіней. Кілька історій з передової», «Ни тоски, ни жалости. Почему украинки участвуют в боях без правил». Ці лонгріди створені за допомогою паралаксу - ефекту руху сторінки з різною швидкістю під час скролу.

Усі лонгріди «Focus.ua» мають оригінальну структуру, містять фото, відео, інфоргафіку, анімацію, клікабельні заголовки та не менш привабливі внутрішні підзаголовки. Це забезпечує зацікавлення читача та повноцінне прочитання об'ємного тексту з яскраво виділеними тематичними та сюжетними акцентами.

Серед регіональних мережевих ЗМІ досить складно натрапити на лонгрід. Якщо використовується така форма подачі об'ємного матеріалу, то це зазвичай традиційна форма створення лонгріду: текст, який доповнений фото та відео, рідше інфографікою. Акценту на технічні ефекти майже немає («Скрипаль на даху синагоги став новою родзинкою екскурсій по Шаргороду». Режим доступу. - http://naparise. com, 04.11.2019).

«Популярність лонгріду варто вимірювати хвилями. Ситуація в країні або несподіваний репост у соціальних мережах популярного блогера може викликати інтерес до вашого лонгріду навіть через півроку після публікації. Але кількість переглядів не визначає якість матеріалу - це не абсолютний критерій. Лонгрід - це рушниця, що висить на стіні, але яка вистрелює декілька разів, періодично» ${ }^{14}$.

\footnotetext{
${ }_{13}^{13}$ Колесниченко, А. (2008), Прикладная журналистика. Учебное пособие, Изд-во Моск. Ун-та, Москва, с. 35

${ }^{14}$ EJO, (2016), «Лонгрід - це рушниця, що вистрілює декілька разів», - редактор Focus.ua», доступно за адресою: https://ua.ejo-online.eu/3276/etyka-ta-yakist/лонгрід-це-рушниця-що-вистрілюєдек (дата перегляду 28 листопада 2019).
} 


\section{5. Результати і перспективи подальших досліджень.}

Отже, серед важливих структурних елементів лонгріду варто виокремити такі: знаковий факт чи акцент на невідомому аспекті цього факту (неординарна ключова особа чи невідома інформація про неї); влучний заголовок та внутрішні підзаголовки, врізи, цитати, ключова метафора (через неї можуть проходити сюжет, певні ситуації), бекграунд, який доповнює основний текст (можливо, виділений окремими тематичними блоками праворуч чи ліворуч від основного тексту). Потребує подальшого обговорення концепція щодо визначення поняття «лонгрід» та визначення його типології. Зважаючи на всі специфічні характеристики, які притаманні лонгріду, варто вважати лонгрід сучасною формою новітніх медіа та виділяти такі типи: лонгрід-портрет, лонгрід-інтерв'ю, лонгрід-аналітична стаття, лонгрід-реконструктор, логрід-фіче, лонгрід ньюс-фіче, лонгрід-репортаж.

\section{6. Висновки.}

Сучасний лонгрід - це своєрідний тренд новітніх медіа, тому його все-таки варто розглядати як форму сторітелінгу, адже він тісно пов'язаний з різними жанрами (репортаж, інтерв’ю, аналітична стаття, портрет, ньюс-фіче, фіче), які стали більш оригінальними завдяки ознакам гіпертекстуальності, мільтимедійності та інтерактивності. Тому лонгрід - це не звичайна новина чи актуальна проблема, це історія, комплексний сюжет. Не просто мультимедійна історія, а нова подача матеріалу, якісний журналістський текст, який зазнав трансформації (містить текст, аудіо, фото, відео, анімацію, інфографіку), орієнтується на багатогранність інтернет-простору та динамічні запити сучасного споживача медіаконтенту. Лонгрід не просто використовує елементи різних жанрів, а слугує специфічною технологічною формою для подання того чи іншого жанру.

\section{СПИСОК ЛІТЕРАТУРИ}

1. Вербовий, Р. (2017), «Інструментарій створення мультимедійного контенту», Шевченко, В. (Ред.), Кросмедіа: контент, технології, перспективи (колективна монографія), Ін-т журналістики Київського нац. ун-ту імені Тараса Шевченка, Київ, 234 c.

2. Горошко, Е., Полякова, Т. (2015), «К построению типологии жанров социальных медиа», Жанры речи, №2(12), с. 119-127.

3. Градюшко, А. (2016), «Современные мультимедийные форматы аналитических жанров журналистики», Вараб’ёв, В. (Ред.), Журналістыка у суладдзі з жыщиём: зб. навук. Праи, БДУ, Мінск, с. 192-197.

4. Колесниченко, А. (2008), Прикладная журналистика. Учебное пособие, Изд-во Моск. Ун-та, Москва, $180 \mathrm{c.}$

5. Колесниченко, А. (2015), «Длинные тексты (лонгриды) в современной российской прессе», Медиаско: электрон. журн. Факультета журналистики МГУ им. М. В. Ломоносова, Вып. 1. URL: http://www.mediascope.ru/node/1691

6. Колокольцева, Т. (2016), «Диалогичность в жанрах интернет-коммуникации (чат, форум, блог)», Жанры речи, №2, с. 96-104.

7. Крецу, І., Гузун, М. та Василик, (2015), Л. Підручникз крос-медіа, Bonn / GermanySibiu/ Romania, Schiller Publishing Youse, 140 c. 
8. Мацишина, I. (2017), «Структура мультимедійного сторітелінгу (на прикладі лонгріду)», Шевченко, В. (Ред.), Кросмедіа: контент, технологї̈, перспективи (колективна монографія), Ін-т журналістики Київського нац. ун-ту імені Тараса Шевченка, Київ, 234 с.

9. Тонкіх, I. (2017), Інтернет-журналістика. Жанри в інтернеті: Навчальний посібник, ЗНТУ, Запоріжжя, $130 \mathrm{c.}$

10. Чабаненко, М. (2018), Мультимедійність в інтернет-журналістиці: Навчальнометодичний посібник для здобувачів ступеня вищої освіти бакалавра спеціальності «Журналістика», Просвіта, Запоріжжя, 80 с.

11. ЕЈO, (2016), «Лонгрід - це рушниця, що вистрілює декілька разів», - редактор Focus.ua», доступно за адресою: https:/ua.ejo-online.eu/3276/etyka-ta-yakist/лонгрід-це-рушниця-що-вистрілює-дек (дата перегляду 28 листопада 2019).

12. WebMaestro, (2018), «Як зробити лонгрід, який дочитають до кінця?», доступно за адресою: https://webmaestro.com.ua/ua/blog/long-read/ (дата перегляду 20 листопада 2019).

\section{REFERENCES}

1. Chabanenko, M. (2018), Multimedia in Internet Journalism: A Textbook, Prosvita, Zaporizhzhya, $80 \mathrm{p}$.

2. EJO, (2016), «Longrid - ce rushnycya, shho vystrilyuye dekil'ka raziv», - redaktor Focus.ua», available at: https://ua.ejo-online.eu/3276/etyka-ta-yakist/лонгрід-це-рушниця-що-вистрілює-дек (accessed 28 November 2019).

3. Goroshko, E., Polyakova, T. (2015), «The typology of social media genres», Zhanry ryechi, №2 (12), pp. 119-127.

4. Hradyushko, A. (2016), «Modern multimedia formats of analytical genres of journalism», Varab'ev, V. (Ed.), Journalism with life, BSU, Minsk, pp. 192-197.

5. Kolesnichenko, A. (2008), Prykladna zhurnalistyka. Textbook, Moscow Publishing House. Univ., Moscow, $180 \mathrm{p}$.

6. Kolesnichenko, A. (2015), "Long texts (longread) in the modern Russian press», Mediasko: electron.magazine of Journalism, Moscow State University by M.V. Lomonosov, issue 1. URL: http://www.mediascope.ru/node/1691

7. Kolokoltseva, T. (2016), «Dialogue in the genres of Internet communication (chat, forum, blog)», Zhanry ryechi, №2, pp. 96-104.

8. Kretsu, I., Guzun, M. and Vasilik, L., (2015), L.Cross-media: textbook, Bonn / Germany - Sibiu / Romania, Schiller Publishing Youse, 140 p.

9. Matsyshina, I. (2017), «The structure of multimedia story (on the example of a longread)», Shevchenko, V. (Ed.), Crossmedia: Content, Technologies, Perspectives (Collective Monograph), Institute of Journalism of Kyiv National University by Taras Shevchenko, Kyiv, 234 p.

10. Tonkih, I. (2017), Internet journalism. Genres on the Internet: Textbook, ZNTU, Zaporizhzhya, $130 \mathrm{p}$.

11. Verbovyi, R. (2017), «Creation of multimedia content», Shevchenko, V. (Ed.), Crossmedia: Content, Technologies, Perspectives (collective monograph), Institute of Journalism of Kyiv National University by Taras Shevchenko, Kyiv, 234 p. 
12. WebMaestro, (2018), «Yak zrobyty longrid, yakyj dochytayut do kincya», available at: https://webmaestro.com.ua/ua/blog/long-read// (accessed 20 November 2019).

\title{
THE LONGREAD AS A FORM OF MODERN MULTIMEDIA JOURNALISM
}

\author{
Ulyana Leshko \\ Vinnytsia State Pedagogical University named after Mykhailo Kotsubynsky, \\ 32, Ostrohsky Str., 21100, Vinnytsia, Ukraine \\ e-mail:leshkol@ukr.net \\ https://orcid.org/0000-0003-1260-3354
}

The article deals with theoretical analysis of the longread and it's functioning as a modern form of Internet media. The structural elements of the longread, the main types, the specificity of using multimedia stories by modern online media are analyzed. It is revealed that Ukrainian Internet's genrology needs a single concept to define the term «longread». The longread is a modern form of the new media and it is possible to allocate a types of longread: longreadportrait, longread-interview, longread-analytical article, longread reconstruction, longreadfeature, longread news-feature

The modern longread is a kind of trend of the new media, so it should still be considered as a form of storytelling, because it is associated with genres: reportage, interview, analytical article, portrait, news-feature, feature. They have become more original because they have signs of multimedia, interactivity and hypertextuality. Longread is not ordinary news or actual problem, it is a story, a complex topic. It is not just a multimedia story, but a new presentation of material, a quality journalistic text that has been transformed (has a text, audio, photos, videos, animation, infographics), focuses on the multifaceted nature of the internet and the dynamic requests of the modern consumer of media content. Longread is a specific technological form for representing one or the other genre.

Key words: longread; multimedia story; Internet journalism; multimedia journalism; new media. 